\title{
Book Reviews for Mathematics Undergraduates: an assignment to enhance reading and writing skills essential for today's workplace and to promote collaboration between library and academic staff'
}

\author{
Noel-Ann Bradshaw, School of Computing \& Mathematical Sciences and Karen Richardson, \\ Information \& Library Services
}

\begin{abstract}
This case-study shows how successful collaboration between colleagues from the University of Greenwich library and Mathematical Sciences department has resulted in increased library usage and an improvement in important employability skills for mathematics students. It is argued that similar collaborations in other STEM disciplines within the University could have an equally beneficial effect.
\end{abstract}

\section{Background}

'The importance of developing the communication skills of mathematics undergraduates has long been recognised by both universities and graduate employers' (Groves, 2012). In 2002 Challis et al (2002) stated that employers of mathematicians 'require good transferable skills, such as reading, writing, speaking and working with others, as well as subject-specific knowledge'. However there is evidence that mathematics and indeed other science graduates do not come by these skills easily. The Roberts' Review commissioned by HM Treasury in the same year (Roberts, 2002), found that 'there are mismatches between the skills of [SET] graduates and postgraduates and the skills required by employers (for example, many are seen to lack strong transferable skills)'.

Since then, university mathematics and science departments have done much to try and rectify this deficiency and there have been a number of HE STEM projects commissioned with these aims in mind, many of which are discussed by Rowlett (2012). As an institution we have seen the importance of encouraging these skills reflected in the Greenwich Graduate Attributes such as enabling students to develop 'the ability to be fluent and articulate in oral communication, in ways that are tailored to different audiences' and also 'sophisticated writing skills'.

Nowadays there are very few jobs where the mathematics or science graduate can hide behind the analytical knowledge they possess and avoid conversation with the outside world. Knowledge of their discipline is not enough; they need to be able to communicate their findings clearly to management, clients and colleagues in a variety of formats.

\section{Introduction}

In 2008 one of the authors was given the task of creating suitable Personal Development Planning (PDP) material for first year maths students. It was well known in the department (and indeed the sector as a whole) that mathematics students in particular are not noted for their communication skills: 'mathematics graduates tended to lack presentation and communication skills (including report writing and presentation to a non-technical audience)' (Challis, 2002). This is a serious problem when soon-to-be graduates start applying for graduate jobs and one that needed to be addressed. 
As well as delivering the usual study skills material, she was keen to encourage new students to use the library and to expose them to the multitude of popular mathematics books that now existed, such as Letters to a Young Mathematician by lan Stewart and Simon Sing's The Code Book. Books like these are not difficult to read and give students broader knowledge of their subject and of the practice of contemporary professional mathematicians. She felt that becoming more familiar with the library in the first year would lead to a greater use of it in second and final years, which would have an impact on research undertaken for final year projects. Collaboration with the library staff was going to be at the heart of the success of this assignment.

\section{Identification of "Maths Good Reads"}

The idea of identifying a special set of books for the maths students to read was put to the second author, who is the Librarian with special responsibility for the School of Computing and Mathematical Sciences, with a request for assistance as to how these books could be made identifiable to students.

After much consideration, it was decided to highlight certain books with a green sticker at the top of each spine to enable students to see them easily. Somewhat harder to decide on were the words to go on these stickers, and with much playing around of words, it was decided that "Maths Good Read" was short enough to fit on the stickers and also made clear the significance of the books.

After the initial labelling by academics, the library staff took on the job of monitoring the stock to ensure any duplicate titles that were on loan at the time received a label when they came back, and to label new titles ordered after the initiation of the project. Occasional visits during the summer vacation have been made by the academics, to check the stock and ensure that they are satisfied that all books are fit for purpose. Changes have been made where appropriate.

\section{Assignment}

Having found a way to identify these books in the library, the task now was to create an assessment that encouraged first year maths students to read the books, make use of the library and practice their writing skills. We could tell them about the library, we could arrange a visit and enthuse about 'Maths Good Reads', but would all the students engage?

We already had assignments in place that addressed the skills of writing management reports and dissertations, and giving presentations to groups of non-specialists. However there was nothing that required students to read a text, summarise the contents and reflect on what they had read: all of which are valuable practical and academic skills.

It was decided to ask first year students to choose one of these books and write a review of it. This would help their reading and writing skills, broaden their mathematical horizons and increase their use of the library. At least this was the intention.

Rather than introduce this at the start of term when the new students were overloaded with information, it was planned to introduce it in week five when they had found their feet and were beginning to be set coursework necessitating the use of the library's resources. 
The students were given an introduction to the assignment as part of their PDP training which showed examples of suitable books. It was explained that the task was to write 550 words on why they would recommend their chosen book to one of their fellow students. They were asked to provide a brief synopsis of the book and comment on the following areas:

- What you enjoyed about the book

- Who the book is aimed at

- The style in which the book is written

- Any criticisms you may have

After this the students were taken to the library for a tour and some training on electronic resources and their attention was drawn specifically to the 'Maths Good Reads', in all parts of the library.

\section{Reviews}

The first year this was implemented was rather nerve-wracking. How would maths students react to being required to read and write about a book albeit a book that would be of interest to them? Interestingly the HEA Mathematics publication MSOR Connections was also on the lookout for well-written student book reviews so this was mentioned when the assignment was issued, adding weight to our directions. In the event, reading the students' reviews showed us why this had been a worthwhile assignment. A number of students had started their reviews with sentences such as,

"To be honest, I wasn't really excited to read a book, especially a maths book. I cannot remember the last time I read one."

But then concluded by saying, for example,

"After reading this book, I know that maths is such a beautiful subject which is sadly hidden away in the classrooms but all is revealed in this book, well nearly everything. I eagerly advise each and every student who is studying maths or a maths based subject, to read this book as this book is aimed at that specific group. It will make you see maths in a different way."

Another student said:

"I'm shocked that I have never been so hooked on a book in all my life! In the twenty one years up until I started university I managed to avoid reading a book. When I was asked as part of my university course to review a book the idea was very daunting and a task which I knew I would not be confident about. Thankfully it was one of the best things I have done whilst I have been there."

And another who was already an avid reader of fiction but not of non-fiction said of the assignment,

"I would say it has changed my general reading patterns as I am now delving into more and more non-fiction material, something I would never have been thoroughly comfortable with prior to writing the book review." 
Since this we have published excerpts of the reviews in our University MathSoc newsletter Prime Times which is distributed to all potential new maths students who visit our open days. On the back of this assignment we were also able to recommend one of our best reviewers to Times Higher Education (THE) who commissioned her to write a review (Fawthrop, 2011).

\section{Data Analysis}

The loan histories of a small sample of students were examined. The data indicated that those who borrowed Maths Good Reads, borrowed more books as a whole. Not unexpectedly there is a moderate to high correlation between the number of 'Maths Good Read' books that these students borrowed and the total number of books that they borrowed during their time at the University. This implies that encouraging the students to borrow these books in the first year has a positive effect on their use of library resources later on.

Qualitative research was simply based on the perceptions of library staff on the movement of maths stock as a whole and Maths Good Read Books in particular, especially the opinions of shelving staff. All staff questioned said there was a noticeable increase in the movement of stock including those with green stickers.

We have also looked at evidence of the students' acquisition of employability skills. In the National Student Survey 2010/11 (the students that were in the first cohort to have taken this assignment) questions 19 and 20 relate to Students' Confidence and Communication Skills respectively and both are attributes that we have been keen to see increase. In both of these we are well above the sector average being in the top $20 \%$ for question 19 and the top $11 \%$ for question 20, an improvement on the scores for the previous year.

We have also looked at the Destination of Leavers from Higher Education Survey (DHLE). This shows an increase of $13 \%$ of our maths graduates entering full-time employment from the cohort that first completed this assignment. However it must be said that there have been many other initiatives in place across the University as well as in School that could have contributed to this effect. This point notwithstanding, we would hope that this has contributed to the employability skills that employers are looking for and to students' confidence.

\section{Changes for the future}

It has been noticed by library staff that the students are not required to borrow these books for this assignment from the library so some are obtaining copies from other libraries or even buying them. Whilst we do not want to do anything to discourage the students from reading books that they have obtained elsewhere it would be helpful if we could encourage them to use the designated books at Greenwich. The coursework specification could be changed to emphasise this.

We have a list of books with green stickers that we can pass on to interested staff and students alike. However for students it would be helpful to have a couple of lines of description about each book but this takes time to compile.

\section{Conclusion}

In terms of meeting the learning objectives, this assignment has been a great success. Students have been challenged to read more and they are undoubtedly doing this and are 
enjoying the books that they are reading. At both ends of the academic and social spectrum students have been reading a wider variety of books and have been exposed to different styles of writing. Their choice of books has in many cases had a bearing on the final year projects that they have undertaken and students seem more confident and comfortable at undertaking research in the library.

The evidence suggests that the introduction of this assignment in the first year and collaboration between mathematics academics and library staff has resulted in students who are making more use of these books in the library and of the library facilities in general.

The relationship which has been established between academic and library staff has been a very valuable additional benefit from this project for the department, school and library.

\section{References}

Challis, N., Gretton, H., Houston, K., and Neill, N. (2002). 'Developing transferable skills: preparation for employment'. In Kahn, P. and Kyle, J. (eds) Effective Teaching and Learning in Mathematics \& its Applications. London: Kogan Page, 79-91.

Fawthrop, R. (2011). [Student review] '1089 and All That: A Journey Into Mathematics'. The Times Higher, 26 May 2011. Available at:

http://www.timeshighereducation.co.uk/story.asp?sectioncode $=26 \&$ storycode $=416322$ (Accessed 6 February 2013).

Groves, J.S. (2012). 'Enhancing the communication and speaking skills of mathematics undergraduates'. In Rowlett, P.(ed), Further Work Developing Graduate Skills in HE Mathematics Programmes. Birmingham: MSOR HESTEM, 19-22.

Rowlett, P. (2012). Further Work Developing Graduate Skills in HE Mathematics Programmes. Birmingham: MSOR HESTEM.

Sing, S. (2002). The Code Book: The Secret History of Codes and Code-breaking. London: Fourth Estate.

Stewart, I. (2006). Letters to a Young Mathematician. New York: Basic Books.

\section{Author Biographies}

Noel-Ann is a university teaching fellow and principal lecturer of mathematics and operational research in the School of Computing and Mathematical Sciences. She was responsible for looking after first year maths students for several years but has now taken on the role of School admission tutor.

Karen is the academic services librarian for the School of Computing and Mathematical Sciences. Karen likes to look at fun ways of engaging with the students, including playing logical board games with the maths student in the Maths Arcade and learning Pi to 72 decimal places with the aid of the Dewey Decimal System. 
Case Studies

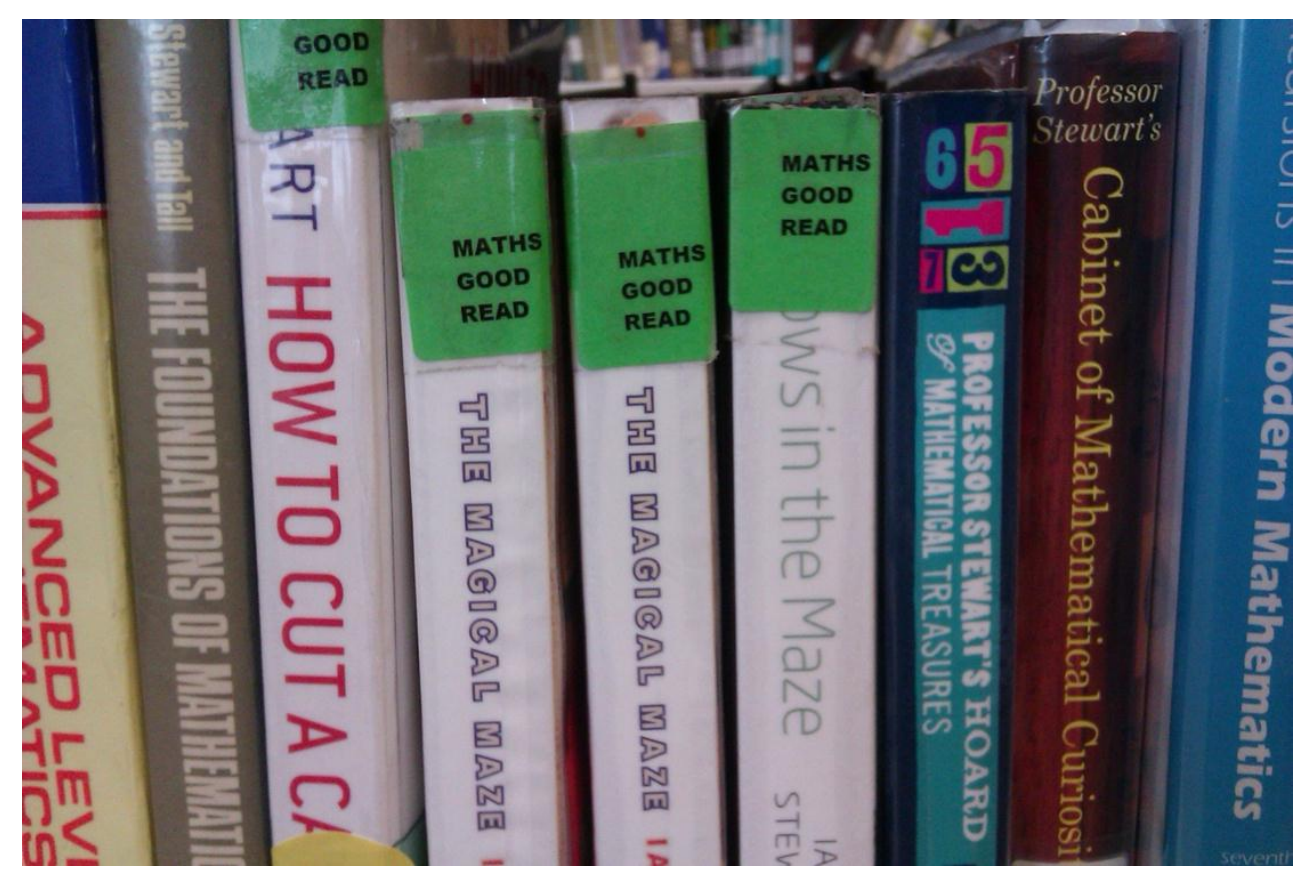

